\title{
Multi-donor trust funds and fragile states: assessing the aid effectiveness of the Zimbabwe multi-donor trust fund
}

\author{
Davison Muchadenyika
}

\begin{abstract}
:
It is widely acknowledged that multi-donor trust funds (MDTFs) contribute to aid effectiveness. This paper challenges this assertion through assessing the aid effectiveness of the Zimbabwe Multi-Donor Trust Fund. The paper makes four key arguments. First, political relations between recipient and donor countries are vital in the functioning of MDTFs. Second, the design of MDTFs affects the delivery and functioning of the trust fund. Third, whilst the legitimacy of national governments in fragile states is often contested, targeting legitimate and credible institutions can offer tangible and life changing results. Fourth, MDTFs focusing on the recovery of key sectors such as water, sanitation and energy have direct impacts to economic recovery and people's lives.
\end{abstract}

\section{INTRODUCTION}

Multi-donor trust funds (MDTFs) are a prevalent aid mechanism in international development. In particular, MDTFs are often predominant in fragile states. This raises a number of questions such as how do MDTFs contribute to aid effectiveness? Under what conditions can MDTFs in fragile states contribute to aid effectiveness? Fragile states are an eminent challenge of international development policy. They are more susceptible to instability, with potential regional and global consequences (OECD, 2013). High levels of poverty, inequality and vulnerability are key defining features of fragile states. Thus, the key focus of international development is to avoid the degeneration of fragile states into state failure.

Recent studies indicate the changing face of fragility in which addressing fragility as a deeply political issue centred on the social contract between the state and society is critical (OECD, 2013). In particular, it is essential to improve the capacity of the state to deliver public goods and services to its citizens. This approach compels international development assistance to focus on the re-establishment and reinforcement of the social contract, a phenomenon that brings mutual trust and credibility between the state and society.

Aid effectiveness and improving the impact of aid, especially in fragile and conflict affected states has become a major policy issue for many international development organisations and bilateral donors (Barakat et al., 2011). Delivering aid in fragile contexts is difficult and 
risky as most recipient countries are characterised by weak state policies, weak institutions, and high incidences of the relapse of conflict and instability. Despite these risks, financial analysis reveal that since 2000, aid volumes have increased with fragile and conflict affected states receiving a substantial amount (Chapman \& Vaillant, 2010). In this context, what form of aid instrument is prevalent in fragile states?

The central financing vehicle increasingly in use in fragile and conflict affected situations are MDTFs (World Bank, 2011). By definition, trust funds are vehicles of channelling aid resources from governmental and non-governmental donors, administered by a trustee organisation (IEG (Independent Evaluation Group), 2011). Donor organisations and recipient countries agree on who administers and manages the fund. The complexity of challenges in post-crisis situations calls for collective engagement as no single agency can provide adequate support (OECD, 2012). MDTFs provide an avenue for such collective engagement. At the centre of the emergency of MDTFs as a popular aid financing mechanism is the push to enhance aid effectiveness amongst the international community (Barakat et al., 2011).

International engagement in fragile states involves dealing with uncertainty, fluidity and high risk. In such high risk environments, the international community is prone to relying on bilateral and multilateral organisations to perform functions normally performed by the state as a way of dissociating with corrupt use of resources and violence unleashing regimes (World Bank, 2011). Here, the goal is to use credible, less risky systems and avoiding parallel systems that further weaken or undermine the state. High risk environments are difficult to engage as they require extensive compromise in designing aid mechanisms. MDTFs have been used as a risk adverse mechanism in high risk environments. The 2011 World Development Report argues that MDTFs improve the transparency of donor investments, reduce transaction costs, ensure greater coherence with national planning and provide a platform for resource mobilisation, donor coordination and dialogue with national authorities (World Bank, 2011). Thus, MDTFs are an important tool of achieving aid effectiveness.

Zimbabwe is a fragile state, ${ }^{1}$ and the international donor community's collective response revolves around five MDTFs, namely, the Education Transition Fund, and Health Transition Fund (both UNICEF managed), Analytical Multi-donor Trust Fund and Resultsbased Financing Trust Fund (both World Bank managed) and the Zimbabwe Multi-donor Trust Fund (Zim-Fund) (African Development Bank managed). The purpose of this article is to determine the Zim-Fund adherence to Paris Declaration principles on aid effectiveness. The Paris Declaration is recognised for its provision for a practical and action-oriented roadmap, and a clear monitoring framework to track the progress with indicators and targets (Kim \& Lee, 2013). This is performed primarily for two reasons. First, the MDTFs are widely believed as aid instruments that enhances aid effectiveness in fragile states (World Bank, 2011; Barakat et al., 2011). Using the Paris Declaration principles, this article

\footnotetext{
${ }^{1}$ On the World Bank's Country and Policy Institutional Assessment index, Zimbabwe is classified a fragile state with its ranking falling from 3.3 in 1999 to 1.76 in 2007 and 1.67 in 2008 before recovering to 2.4 in 2011.
} 
challenges this assertion through assessing the aid effectiveness of the Zim-Fund. The article argues that, the institutional structure of a trust fund, and politics are important factors that determine the aid effectiveness of a trust fund. Second, it is vital that MDTFs be assessed not in general but with context specificity. In this regard, the unique nature of fragility in Zimbabwe provides vital insights to MDTF literature.

The structure of the article is as follows: Section 2 explains the currency of MDTFs in mainstream development thinking and practice. Section 3 reviews the aid effectiveness debate. In Section 4, the article explains the context of Zimbabwe's development and aid dynamics. A brief overview of the Zim-Fund is proffered in Section 5 with Section 6 outlining the research methodology. Section 7 presents and discusses the research findings while Section 8 concludes the article.

\section{MULTI-DONOR TRUST FUNDS}

Multi-donor trust funds have quickly become one of the most prominent aid modalities (Barakat et al., 2011). There are primarily two types of MDTFs, namely, governmentmanaged and donor-managed. The former are managed by government arms or agencies tasked with both fund management and implementation of fund projects. In practice, government-managed trust funds are few, as MDTFs are normally used in situations where government and state capacity is considered weak. Zimbabwe has five operational MDTFs, all of them donor-managed. However, the contribution of MDTFs in improving aid effectiveness is contested in development theory and practice. This is despite the overall conception that in fragile states, MDTFs contribute significantly to aid effectiveness. According to Feeny and McGillivray (2009), MDTFs are an important step in reducing transaction costs of aid delivery and adhering to the Paris Declaration. Basing on a study in the West Bank and Gaza, Bosnia and Herzegovina, East Timor (Timor-Leste) and Afghanistan, Schiavo-Campo (2003) concludes that MDTFs contribute to aid effectiveness in situations characterised by agreed programmes of reconstruction activities, ownership by both government and donors, transparency and citizens' voice. In this regard, it is crucial to assess the design, management, accountability and ownership of MDTF programmes by government and donors.

In donor-managed MDTFs, many donors perceive that there are very limited opportunities for recipient governments to take effective ownership of a development agenda and provide a voice and coordination that is required to deliver on alignment and harmonisation (Manuel et al., 2012). Donor-managed MDTFs have challenges in adhering to aid effectiveness principles of ownership and alignment. Conversely, recipient government-managed MDTFs have difficulties in terms of management for results as the state is often weak and under-capacitated to perform such functions. Using cross-country research evidence from three fragile states Coppin (2012) finds that MDTFs in general have the potential to strengthen aid effectiveness although aid effectiveness benefits do not accrue automatically. Following this argument, arriving at conclusions about the aid effectiveness of MDTFs is a long process that requires a considerable period of analysis. 


\section{AID EFFECTIVENESS: FRAMEWORK OF ANALYSIS}

Aid effectiveness is a central theme in international development policy and practice. Over the last decade, propelled by aid effectiveness literature, the aid sector has increasingly strengthened its focus on results (Koster \& Holvoet, 2012). In principle, the main purpose of aid effectiveness is contribution to poverty reduction and economic growth. However, aid's effectiveness in raising economic growth and reducing poverty is a topic of longstanding and rigorous debate amongst researchers (Addison et al., 2005). There is extant literature on both the affirmative and negative as discussed in ensuing paragraphs. At the core of the aid effectiveness agenda is the ability of recipient countries to take ownership and responsibility in devising poverty reduction development strategies and a global commitment to tangible target-led development results (Mawdsley et al., 2013). Poverty Reduction Strategy Papers and Millennium Development Goals are development packages designed and intended to improve aid effectiveness. Despite large aid volumes being channelled to fragile states, recipient countries often lack the absorptive capacity to efficiently use aid flows (Feeny \& McGillivray, 2009). Thus, a considerable amount of aid flows can be wasted. Poverty reduction development strategies and the capacity of the state to manage aid flows are important indicators of aid effectiveness.

The widely used measure of aid effectiveness is the Paris Declaration on Aid Effectiveness, which outlined the principles of ownership, alignment, harmonisation, management for results and mutual accountability as broad aims of the aid effectiveness agenda. The principles are defined in Table 1.

The central empirical question is how the principles outlined in Table 1 are implemented and play out in practice. The Paris Declaration provides a framework to enable evidence- based dialogue to improve aid practices and its impact on development on the ground (Killen \& Rogerson, 2010). This article selects 20 indicators of the principles outlined in Table 1 based on partner commitments and progress indicators outlined in the Paris Declaration on Aid Effectiveness (as explained in Section 6). This selection is informed by progress indicators showing partner commitments, which can be measured nationally. Improving aid effectiveness in fragile states entails external actors focusing on state building as a central objective (OECD/DAC, 2007). This transacts in the development of pro-poor development strategies aimed at transforming people's lives through responsive state institutions.

The article uses the Paris Declaration as a framework of analysis for specifically three reasons. First, the Paris Declaration principles are widely used as indicators of aid effectiveness (Rogerson, 2005; Odén \& Wohlgemuth, 2011; Koster \& Holvoet, 2012). Second, the MDTFs are viewed as an important step in adhering to Paris Declaration principles (Feeny \& McGillivray, 2009). Third, the Zim-Fund is a vehicle that aims at enhancing aid effectiveness through harnessing donors towards a common aid delivery channel. 
Table 1. Principles of aid effectiveness

\begin{tabular}{ll}
\hline Principle & \multicolumn{1}{c}{ Definition } \\
\hline Ownership & $\begin{array}{l}\text { Partner countries exercise effective leadership over their development } \\
\text { policies and strategies and coordinate development actions. } \\
\text { Donors base their overall support on partner countries' national development } \\
\text { strategies, institutions and procedures. }\end{array}$ \\
Alignment & $\begin{array}{l}\text { Donors' actions are more harmonised, transparent and collectively effective. } \\
\text { Marmonisation }\end{array}$ \\
$\begin{array}{l}\text { Managing for results } \\
\text { Mutual accountability }\end{array}$ & Donors and partners are accountable for development results. \\
\hline
\end{tabular}

Source: Paris Declaration, 2008.

\section{ZIMBABWE'S DEVELOPMENT CONTEXT AND AID DYNAMICS}

For the second decade running, the role and capacity of the Zimbabwean state in international aid management and public service delivery is weak (UNDP, 2009, 2010). Thus, the international community (donors) has been helping the state perform its basic functions of public service delivery. There are three key events, which contributed to the weakening of the state's role in the development process and changing development context and aid dynamics in Zimbabwe. These are the huge unbudgeted gratuities to war veterans in 1997 triggering the Zimbabwean dollar to lose half of its value on a single day (ICG (International Crisis Group), 2004); economic destabilisation following the chaotic and contested fast track land reform programme (beginning 2001) (Dore, 2009) and the formation of the opposition Movement for Democratic Change (MDC) in 1999. The Zimbabwean state responded by being oppressive disregarding the rule of law, human rights and media freedom (OSISA, 2007). These developments prompted donors to opt for nonstate actors as recipients in channelling aid. Thus, at the turn of the millennium, Zimbabwe entered a period of unprecedented socio-economic and political crisis.

The response of the Zimbabwean state to the looming crisis brought significant and drastic changes to aid delivery and management in the country. On the other hand, the US Government enacted the Zimbabwe Democracy and Economic Recovery Act (ZIDERA) in 2001 aimed at providing a 'transition to democracy and promoting economic recovery in Zimbabwe' (Zimbabwe Democracy and Economic Recovery Act, 2001). The ZIDERA Act empowered the US Government and its representatives to vote in multi- lateral financial institutions (MFIs) against any extension of loans, credit, or guarantee to the Government of Zimbabwe and any cancellation or reduction of indebtedness owed by Zimbabwe to USA or any MFIs. Zimbabwe became ineligible to access any development finance from the Bretton Woods institutions. Further, the US Government cancelled Official Development Assistance (ODA) to the Government of Zimbabwe preferring funding non-governmental organisations involved in governance, democracy and humanitarian work (UNDP, 2009). The European Council Decision (2002/145 CFSP) of 18 February 2002 introduced 
restrictive measures against the Government of Zimbabwe. ${ }^{2}$ As a result, European donors evaded the Government of Zimbabwe and provided ODA through non-state actors.

The economic crisis severely eroded the country's development gains. Zimbabwe's gross domestic product declined by 37 per cent between 1998 and 2006 (Zimbabwe Institute, 2007: 37). By 2006, life expectancy had dropped to the lowest in the whole world: 34 years for women and 37 years for men (UNDP, 2008). Beginning 2008, the Zimbabwean dollar lost its value completely. To support the said assertion, by July 2008, a loaf of bread was costing nearly ZW $\$ 100$ billion (Dore, 2009: 18). The delivery of public services reached near collapse as 60000 of the 140 ooo teachers remained at their posts and 30 per cent of government health workers were still at their posts (Dore, 2009). Amid public service delivery collapse, a widespread and endemic cholera broke out claiming over 4000 lives (ICG (International Crisis Group), 2009). Mbeki, (2009: 101) argues that the Zimbabwean case was the making of a failed African state in which everything had gone wrong-economics, politics, foreign policy and public health to the detriment of the Zimbabwean people.

With little access to development financing, isolated from the international community, ruled by a repressive regime, distrusted by citizens and challenged by the MDC-the Zimbabwean state was at its weakest (Muchadenyika, 2013). The harmonised elections ushered in a transitional phase guided by the Global Political Agreement, 3 and new aid modalities emerged. Mbeki (2009) argues that the development conditions facing the Inclusive Government were complex as all sectors of the economy had collapsed. Other scholars such as Mbeki (2009); Acemoglu and Robinson (2013) and the Failed States Index categorised Zimbabwe as a failed state. The Failed States Index ranked Zimbabwe second (2009), fourth (2010), sixth (2011), fifth (2012) and 10th (2013).

Because of the political construction of the Inclusive Government (for instance, the rise of MDC in government), aid dynamics changed as donors prioritised re-engaging the Government of Zimbabwe, though cautiously (Muchadenyika, 2013). The process of state re-engagement in aid management resulted in the creation of five MDTFs, namely, the Health Transition Fund, Analytical Multi-donor Trust Fund, Education Transition Fund, the Zim-Fund and Results-based Financing Trust Fund. ${ }^{4}$ These trust funds are financing the provision of key services such as health, education, electricity, water and sanitation in addition to supporting

\footnotetext{
2 Council decision premised on violence escalation, intimidation of political opponents, harassment of independent press and infringement of the right to freedom of speech, assembly, and association and the violation of norms and standards for free and fair elections. Council decision premised on violence escalation, intimidation of political opponents, harassment of independent press and infringement of the right to freedom of speech, assembly, and association and the violation of norms and standards for free and fair elections.

${ }^{3}$ Signed and entered by the two Movement for Democratic Change formations and Zimbabwe African National Union Patriotic Front.

${ }^{4}$ Donors involved in these trust funds are UK, Japan, Germany, Netherlands and Finland, and the European Commission, Switzerland Development Cooperation Agency, Australian Agency for International Development, Canadian International Development Agency, Danish International Development Agency, Department for International Development, Directorate General of International Cooperation, European Union, Finnish International Development Agency, German Agency for International Cooperation, Norwegian Agency for Development Cooperation, Swedish International Cooperation Agency, United States Agency for International Development and the World Bank.
} 
research and technical assistance and strengthening public management efficiency. On average, ODA increased during the transition period as reflected on Table 2.

The bulk of funds shown in Table 2 were channelled through MDTFs and other non- state development actors. This arrangement is against government's wishes as the government 'bemoan the continued bypassing of government budget structures by development partners' who prefer to channel ODA outside government channels (MoF (Ministry of Finance), 2013: 121). In other words, donors are still to have confidence in the Government of Zimbabwe with regards to international aid management. Non-state actors remain a key financing vehicle used by donors in funding and assisting government development programmes.

In summary, Zimbabwe shows an unusual case of state fragility, which has resulted in the setting up of five MDTFs. Unusual in the sense that countries such as West Bank and Gaza, Bosnia and Herzegovina, East Timor (Timor-Leste), Liberia, South Sudan and Afghanistan (Schiavo-Campo, 2003), which have MDTFs have in one way or another been engaged in serious armed conflict. Further, unlike in many countries where there are operational MDTFs as a way of building state capacity, Zimbabwe does not suffer capacity challenges. Rather, the Zimbabwean issue is the political stand-off between the government and major western nations. It is envisaged that the Zimbabwean case study contribute insights in the broader MDTF literature largely due to its unique setting explained in this article.

Table 2. Official Development Assistance (ODA) actual expenditure figures in Zimbabwe (20092013)

\begin{tabular}{lccccc}
\hline Agency & 2009 & 2010 & 2011 & 2012 & 2013 (pledges) \\
\hline Bilateral partners & 650748630 & 587436642 & 179170524 & 709800000 & 53487272246 \\
Multilateral partners & - & 30083718 & 26577463 & 224600000 & 33649765 \\
Grand total & 650748630 & 617520361 & 205747987 & 934400000 & - \\
\hline
\end{tabular}

Sources: Ministry of Finance, 2011a, 2011b, Ministry of Finance, 2012a, $2012 \mathrm{~b}$ and Ministry of Finance, 2013.

\section{ZIMBABWE MULTI-DONOR TRUST FUND}

The Zim-Fund was created at the request of main donors 5 in Zimbabwe and initially administered by the World Bank. In May 2010, the group of donors requested the African Development Bank (AfDB) to take over the management of the MDTF from the World Bank (African Development Bank (AfDB), 2010a). It was argued that the Government of Zimbabwe was uncomfortable with the World Bank managing the trust fund hence preference of an institution considered 'neutral'-the African Development Bank. The purpose of the Zim-Fund is to contribute to early recovery and development efforts in Zimbabwe by mobilising donor resources and promoting donor coordination. The Zim-

5 These are Department for International Development, Swedish International Cooperation Agency, Switzerland Development Cooperation Agency, German Development Bank, Australian Agency for International Development, Denmark and Norway. 
Fund focuses on the rehabilitation of water, sanitation and energy infrastructure. The governance structure of the Zim-Fund is complex as it consists of a Programme Oversight Committee (POC), a Management Unit (MMU), implementing agencies and the AfDB as shown in Figure 1.

The POC provides the overall oversight functions to the functioning and administration of the Zim-Fund. The POC reviews progress and implementation of the Zim-Fund, and it provides a platform for dialogue between the government, the AfDB and the Zim-Fund donors (African Development Bank (AfDB), 2010b). The POC comprises of two government representatives $^{6}$ and seven participating donor representatives. The MMU is responsible for the collection and quality control of specific project proposals financed under the ZimFund, appraisal and processing of these projects, providing the POC with operational and financial information on the Zim-Fund and facilitating the discussions and decisions of the POC (African Development Bank (AfDB), 2010b, 2010c). The AfDB is both the fund manager and implementing agency. However, the actual implementation of the Zim-Fund projects is performed through two implementing entities contracted by the Government of Zimbabwe. One implementing entity has project management experience in water and sanitation and the other power supply. The water and sanitation implementing entity is a German firm while the power supply implementing entity is a South African company.

The size of the Zim-Fund is determined by the willingness of donors to contribute over time. As of September 2012, donor commitments to the Zim-Fund totalled US\$123.47 million, with US\$101.47 million released to the Zim-Fund account. Two ongoing projects, namely, Urgent Water Supply and Sanitation Rehabilitation Project (UWSSRP) phase I and Emergency Power Rehabilitation Project phase I are at different implementation stages.

${ }^{6}$ Minister of Finance and one minister nominated by government. 


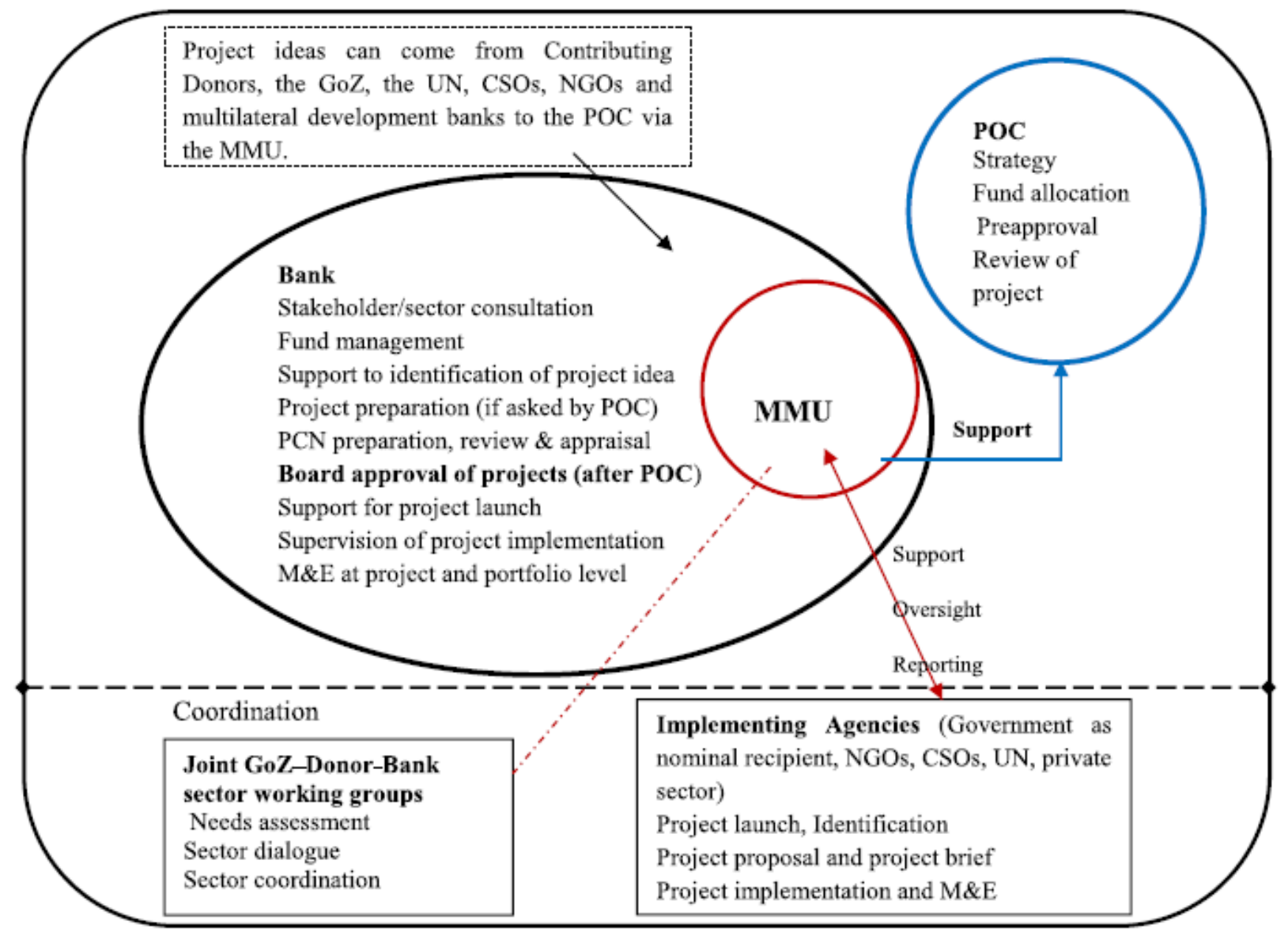

Figure 1. Zim-Fund governance structure (Source: African Development Bank, AfDB, 2010c: 8)

UWSSRP phase I is funded to the amount of US\$29.65 million supporting urgent rehabilitation work and stabilisation of water supply and sanitation services in six municipalities of Harare, Chitungwiza, Mutare, Chegutu, Masvingo and Kwekwe. The project's envisaged outcomes are increased reliability, quality and availability of water supply, restored wastewater treatment capacity and reduced incidence of cholera and other water related diseases.

Emergency Power Rehabilitation Project phase I aims at improving the reliability of power supply through the rehabilitation of Hwange Power Station Ash Plant and the sub transmission and distribution facilities in the country with a grant of US\$35 million. Both projects are being developed to the second phase. Emergency Power Rehabilitation Project phase II is envisaged to continue with the transmission and distribution network rehabilitation and Hwange Ash Plant rehabilitation, and the estimated funding stands at US\$30 million. The second phase of UWSSRP is under preparation with an estimated grant of US\$31 million focusing on four municipalities of Harare, Chitungwiza, Ruwa and Redcliff. Second phase projects are expected to compliment first phase projects. 


\section{RESEARCH METHODOLOGY}

The researcher identified the potential interviewees based on association and experience with the Zim-Fund projects. Thus, data sources were selected based on purposive sampling. There is a defined set of organisations involved in the Zim-Fund, and hence, th researcher selected key informants from that pool. The Zim-Fund, its donors and partners are the core data sources in this article. The article is based on 23 interviews with officials drawn mainly from the Government of Zimbabwe, the Zim-Fund donors and the AfDB as shown on Table 3. The interviewees were selected based on three criteria, namely, those managing the trust fund, donors and representatives of government ministries involved in the trust fund. The interviews were conducted between 1 June and 1 September 2013.

Table 3. List of interviewees

\begin{tabular}{ll}
\hline Name & \multicolumn{1}{c}{ Organisation and department } \\
\hline A1 & Swedish International Development Cooperation Agency, Development Cooperation \\
A2 & Department for International Development, Infrastructure \\
A3 & Australian Agency for International Development, Programmes \\
A4 & Australian Agency for International Development, Programmes \\
A5 & Ministry of Regional Integration and International Cooperation, Development Assistance \\
A6 & Ministry of Finance, Aid Accounting, Funds \& Parastatals \\
A7 & Ministry of Finance, Department of Domestic and International Finance \\
A8 & Ministry of Finance, Department of Domestic and International Finance \\
A9 & Ministry of Finance, Department of Domestic and International Finance \\
A10 & Ministry of Finance, Department of Domestic and International Finance \\
A11 & Ministry of Finance, Aid Accounting, Funds \& Parastatals \\
A12 & Ministry of Finance, Department of Domestic and International Finance \\
A13 & Ministry of Economic Planning \& Investment Promotion, Economics \\
A14 & Zimbabwe Multi-donor Trust Fund, Management Unit \\
A15 & Zimbabwe Multi-donor Trust Fund, Management Unit \\
A16 & Zimbabwe Multi-donor Trust Fund, Management Unit \\
A17 & African Development Bank \\
A18 & UNDP Recovery Strategy Research Team \\
A19 & Economic Development Consultant \\
A20 & Implementing Entity, Programmes \\
A21 & Royal Danish Embassy, Development Cooperation \\
A22 & German Development Bank, Transport and Energy \\
A23 & Switzerland Development Cooperation Agency, Development Cooperation \\
\hline
\end{tabular}

An interview guide (Table 4), with open-ended questions coupled with informal probing facilitated and guided the discussion. The interview guide had five defined categories that are Paris Declaration principles on aid effectiveness (ownership, alignment, harmonisation, mutual accountability and management for results). Four indicators of each principle were selected based on the Paris Declaration commitments and indicators. 


\section{RESEARCH FINDINGS AND DISCUSSION \\ 7.1 Ownership}

The Government of Zimbabwe developed a broad-based development strategy called the medium-term plan (MTP) (2011-2015) GoZ (Government of Zimbabwe, 2011).7

Table 4. Interview guide indicators

\begin{tabular}{ll}
\hline Principle & \multicolumn{1}{c}{ Selected indicators } \\
\hline Ownership & Zimbabwe's operational development strategy. \\
& Operational programmes running under the development strategy. \\
& Participation of development actors in the crafting and implementation of the country's \\
& operational development strategy. \\
& Leadership of Government of Zimbabwe representatives in Zim-Fund operations. \\
Alignment & Design and management of Zim-Fund projects (role and participation of government, \\
& donors and targeted authorities). \\
& Comparison of government development priorities with Zim-Fund priorities. \\
& Zim-Fund strengthening capacity within government of Zimbabwe. \\
Harmonisation & Operational procurement system (any procurement system reforms). \\
& Zim-Fund interface with donors in the country. \\
& Donor common arrangements in practice, that is, planning, M\& E and reporting. \\
& Zim-Fund sharing programme information to donors and the public. \\
& Environmental Impact Assessments and their application in Zim-Fund projects. \\
Mutual & Results accounting by Zim-Fund, donors and the Government of Zimbabwe (joint \\
accountability & assessments on Zim-Fund progress). \\
& Timelines for Zim-Fund reports. \\
& Relationship between Zim-Fund monitoring and government processes. \\
& Accountability to the legislature by government ministries involved in Zim-Fund. \\
Management for & Performance assessment framework. \\
results & Program Oversight Committee roles on Zim-Fund Programmes. \\
& Experience of fund administrator and Zim-Fund Management Unit in managing MDTFs. \\
& Relationship between financial commitments and disbursements by donors. \\
\hline
\end{tabular}

Source: Author's Field Work Interview Guide, 2013.

The plan is implemented through a total of 79 priority projects with an estimated implementation cost of US $\$ 18$ billion in four thematic areas of infrastructure, economic, social, and governance and rights. The government, through the national budget is the main financier to these projects (MEPIP (Ministry of Economic Planning and Investment Promotion), 2012). A government economist argued that 'the Plan provides a unique way of planning and prioritising with little resources' (Interview, A13). At the same time, 'donors have set up five multi-donor trust funds as a way of assisting the implementation of the MTP' (Interview, A1). The First Annual MTP Implementation Progress Report singled out inadequate financial resources as the main constraint to full implementation of the MTP projects (MEPIP (Ministry of Economic Planning and Investment Promotion), 2012). This is despite that there is 'government realisation that some of the national priorities do not need

\footnotetext{
7 The key priorities of the plan are infrastructure development, employment creation, human centred development, entrepreneurship development, macroeconomic stability, Information and Communication Technology and science and technology development, good governance, investment promotion, resource utilisation and poverty reduction (GoZ, 2011).
} 
resources' (Interview, A5). Before the MTP, 'the Government of Zimbabwe had a tendency of producing quality policy documents without consultation, follow-up and feedback resulting in limited implementation' (Interview, A10). However, the government, with support from the UNDP produced the first plan implementation progress report in 2012, which provides a critical assessment of progress and challenges.

The plan was formulated through a highly consultative process that included the government, members of parliament, academia, civil society, UN agencies, MFIs and the diplomatic community (GoZ (Government of Zimbabwe), 2011). In particular, the consolidation of documents presented during consultative meetings and workshops provided the basis of the MTP (Interviews, A13 and A8). The plan consultative process resulted in the compilation of four drafts, with the prepared zero draft tabled to stakeholders for confirming and commenting (Interview, A13). However, while the ZimFund focuses on priorities in the MTP (as discussed under alignment), the Government of Zimbabwe is not directly involved in the management of the fund. Rather, the AfDB is the fund manager with 'government taking a leadership role in identifying priority areas' (Interview, A14). While the government puts down its requirements, 'there is evidence that government does not have the power to influence the fund, making the Zim-Fund to some extent donor driven' (Interview, A20). This is largely due to 'restrictive measures [also referred to as sanctions] imposed on the country's leadership, with donors putting a special arrangement [the Zim-Fund] to circumvent these measures' (Interview, A1). According to the principle of ownership, donors should strengthen government capacity in implementing and managing development programmes such as the Zim-Fund (Rogerson, 2005). Conversely, the Zim-Fund implements and manages projects on behalf of the government, with donors viewing the Zim-Fund as the government providing a unique and complicated situation (Interviews, A1, A3, A5 and A10).

Nonetheless, the POC provides the government with an avenue to influence and provide leadership in the Zim-Fund operations. Despite this caveat, "there are POC sessions where the MMU reports to a POC composed of donors without proper representation from the government side' (Interview, A20). Further, the two implementing entities report to the AfDB (MMU) despite having a contract with the Ministry of Finance. Such arrangement makes the Ministry of Finance, government's representative, 'to be kind of a sleeping partner' (Interview, A20). As a result, there has been a tendency for lack of programme ownership by various government institutions (Interviews, A20 and A21). In other words, the Zim-Fund is an aid instrument to cater for the mistrust between government and donors, with the mistrust constraining government leadership in the Zim-Fund. Perhaps, this explains why seven out of eight government officials argued that government had no option but to agree to any funding arrangement.

While Zimbabwe has a development strategy that involved a number of development actors in its crafting, its implementation has suffered from severe financial constraints. Despite this, non-state actors through MDTFs have been key financiers of programmes supporting MTP implementation. The Government of Zimbabwe is in a weak position to influence the 
operations of the Zim-Fund. This is partly because the government was in a desperate situation hence agreeing to any funding arrangement. However, the government has not exhausted all the avenues to exercise its leadership of the Zim-Fund especially informal POC and project steering committee meetings. Full government participation in informal POC meetings is the key because this is the forum where concrete and detailed discussions take place.

\subsection{Alignment}

Zimbabwe's development priorities are laid out in the MTP. Through the plan, the Government of Zimbabwe identified the availability of reliable water and energy supply as key economic enablers (GoZ (Government of Zimbabwe), 2011). Thus, the Zim-Fund's focus on water and energy 'complements government efforts in resuscitating key development sectors' (Interview, A21). Nonetheless, there are challenges of the Zim-Fund alignment at lower levels that is local authorities and Zimbabwe Electricity Supply Authority. This is evidenced by the fact that 'of the six local authorities and Zimbabwe Electricity Supply Authority, there is little evidence of infrastructure investments plans outlining and defining priorities' (Interviews, A20, A14 and A16). The absence of infrastructure investments plan poses risks of non-continuity at the completion of the Zim-Fund projects. One can argue that poor alignment to local authority plans affects the sustainability of the Zim-Fund projects.

The design and management of projects under the Zim-Fund is complex. The AfDB is the fund manager and the bank standard procedures are used. In general, the 'Bank's procedures are not designed for emergency interventions, since they are slow and have little flexibility for fast reaction' (Interview, A20). Donors give funds to the AfDB to manage the Zim-Fund projects on behalf of the Government of Zimbabwe. This is for political reasons because 'donors are not comfortable with pooled funds channelled through government' (Interview, A2). Such a political context makes alignment to Zimbabwe's systems difficult-which systems donors consider weak and unreliable. Mistrust between donors and the government 'makes the management of the trust fund complex' (Interview, A23). As such, 'the Zim-Fund projects are to a larger extent designed to suit donor needs' (Interview, A10).

However, a government economist likened the situation to a 'taxi driver (the AfDB and donors) and passenger (government), with the latter giving directions though not driving' (Interview, A8). The identification of the projects 'followed a discussion facilitated by the AfDB, with government included somehow, though government did not play a leading role' (Interview, A20). The process of designing projects 'happened very quick and fast, and dialogue with government to define the priorities was probably not given enough time' (Interview, A21). In terms of project design, 'the Ministry of Finance prepares projects in consultation with line ministries and submits the proposals to the AfDB' (Interview, A15). Despite this, the researcher could not find any evidence of documents to support this assertion. Rather, 'donors have to a larger extent been involved in project design evidenced by some donors (UK, Australia, and Denmark) who engaged technical experts to assist the 
project design stage' (Interview, A1). Actual project implementation rests on two implementing entities. The 'complicated structure of project management [with numerous actors and layers] was the overt design of the project' (Interview, A6), something that government could not change. Such a design, however, undermines recipient country systems. Thus, 'the Zim-Fund has to a certain extent been driven by the AfDB though the Bank is supposed to be the facilitator' (Interview, A21). This was attributed largely to the blurred division of labour between government and the AfDB, with the latter acting on behalf of government within the Zim-Fund.

Government ministries are being 'capacitated with short term consultants or specialists seconded by the AfDB to assist in certain areas' (Interview, A9). This is mainly because, the Zim-Fund has 'no capacity building programme aimed at government since it is difficult to work with central government' (Interview, A1). However, for programme sustainability, capacity building is critical. Capacity building happens at project level where operation and maintenance training is given to responsible utilities (Interviews, A15, A16 and A20). However, outside the Zim-Fund, the AfDB has a facility providing technical assistance to the Government of Zimbabwe. This include the capacity building for public and economic management focusing on enhancing capacity for public finance management, improved capacities for MTP implementation, statistical development and regional integration frameworks (AfDB, 2012) ${ }^{8}$

The Zim-Fund uses a separate procurement system because the Zimbabwean procurement system was found to be lacking by the AfDB standards (Interviews, A15, A1, A21 and A10), and is constrained by the challenges facing the State Procurement Board (MEPIP (Ministry of Economic Planning and Investment Promotion), 2012). However, the efficacy of having a procurement agent based in the UK and not Zimbabwe has been queried (Interviews, A21, A22 and A6). The procurement arrangement is meant 'to avoid individuals and companies under restrictive measures to benefit from donor funds' (Interview, A1). Despite engineering firms in Zimbabwe who can produce steel or metal products, the ZimFund procures overseas (Interview, A18), negatively affecting local job creation. Initially, the Government of Zimbabwe 'proposed joint financing of the Zim-Fund, a move refused by donors arguing based on different procurement and reporting systems' (Interview, A16). This is explained by 'the Zim-Fund donors who do not have political permission from their governments to have direct partnership with government' (Interview, A1). In such a political context, donors settled for a channel or fund manager whose procurement rules and regulations they trust. However, the procurement process is 'slow and is to a larger extent donor-controlled leading to project delays' (Interview, A1).

The trust fund is predominantly funding water, sanitation and power generation infrastructure. While the Zim-Fund funding priorities are aligned to government priorities as stipulated in the MTP, the Zim-Fund is a complex structure whose overt design sidelines government in project management. Zimbabwe is a predatory state and resembles features of

${ }^{8}$ Focusing on the Zimbabwe National Statistics Agency, three ministries (finance, economic planning and regional integration) and the Zimbabwe Revenue Authority. 
state capture by a few politically connected elites and cronies. The main political party that controls the levers in government, Zanu-PF believes in primitive accumulation and antidevelopment patrimonialism (Dawson \& Kelsall, 2012). Zanu-PF has control in most companies be it parastatals, or private entities. Some of the companies connected to Zanu- PF are on the US and European Union restrictive measures list, which the Zim-Fund procurement system was intentionally designed to circumvent. Donors pay more attention to politics, and some are applying political analysis to specific aspects of development practice (Unsworth, 2009). Politics is at the centre of the design and management of the Zim-Fund, with donors exerting excessive control. Donors justified such control as premised on the absence of political permission from their governments to have direct partnership with government.

\section{7•3 Harmonisation}

The Zim-Fund interface with donors is through the POC meetings. The POC is supposed to meet quarterly as defined in the Operations Manual but in practice the POC meets twice a year' (Interview, A1). The POC often 'confirms what stakeholders would have agreed on previous POC informal meetings' (Interview, A15). In 2012, the POC met twice in terms of formal meetings. Informally, the POC met six times and 'these are the meetings where intensive discussions take place' (Interview, A21). The participants of the six informal POC meetings were mainly donors, the AfDB (MMU) and 'government participated in half of these meetings' (Interview, A21). Such POC meetings are acting as vital means of providing oversight and direction to the Zim-Fund projects. However, there is no evidence of such meetings being used as a way of harmonising donor projects in Zimbabwe outside the Zim-Fund projects.

Donors use a harmonised planning, monitoring, evaluation and reporting system. This is performed through 'donors actively involved in the drafting of planning documents through workshop participation, commenting on draft documents and engaging technical experts' (Interview, A16). However, 'the Bank has been very slow in preparing a harmonised monitoring and evaluation (M\&E) framework since there has been an over-focus to begin the implementation phase' (Interview, A21). Thus, in 2012, donors were keen in establishing an M\&E framework to justify and legitimise further funding (Interviews, A1, A23, A21 and A22). Fund implementation started in December 2011, and as of August 2013, after the actual infrastructure rehabilitation work had commenced, there was no M\&E framework. All donors interviewed expressed concern over the finalisation of a common and shared M\&E framework. The Zim-Fund reporting system shows features of a harmonised system as similar reports are send to all the donors and partners. However, the harmonisation does not show signs of a planned and developed reporting system by the participating donors. Primarily, this is because progress reports are not standardised, as the reporting system is largely at the hands of the MMU, which can change the format and style of reporting when it deems so.

At this point, focus is placed on sharing of information to donors and government as stipulated in the Paris Declaration. The donor co-chair meets with the Zim-Fund manager at 
least once every month to discuss key emerging issues (Interview, A21). More so, the MMU prepares monthly brief reports showing projects progress and challenges, and these are shared to all donors and government. In the beginning, 'the MMU produced very comprehensive reports which donors found not very useful' (Interview, A2). The donor cochair 'stressed the importance of a communication strategy focused towards the broader Zimbabwean audience and not immediate stakeholders' (Interview, A21). At the time of completing field research, a development communication strategy had been developedprimarily to communicate programme information to the wider public.

In addition, the AfDB's Environmental and Social Assessment procedures further guide the projects demonstrating inclusion of environmental and social components within the overall Zim-Fund guiding documents. Despite the Zim-Fund founding documents outlining key environmental and social issues of focus, there is evidence of wide gaps in acknowledging the specific contextual realities of the Zimbabwean operating environment and absence of clarity on how the Zim-Fund as an emergency fund was going to address environmental and social impacts, which were already affecting specific populations (Cleary et al., 2013). Contrary to planned mitigation measures, at the time of the midterm review, the Zim-Fund was not addressing negative environmental and social impacts to communities.

The Zim-Fund is a funding mechanism that is contributing to harmonisation of donor activities in Zimbabwe. Through the informal and formal POC meetings, the Zim-Fund offers a platform for donor interface. The POC brings together seven Zim-Fund donors (Department for International Development, Australian Agency for International Development, Swedish International Cooperation Agency, German Development Bank, Swiss Agency for Development and Cooperation, Denmark and Norway), and two observers (UNDP and the World Bank). Moreover, the Zim-Fund has also participated in major donor coordination activities such as Infrastructure Technical Review Group, and Urban WASH (water, sanitation and hygiene) meeting with most donors in the country. This is an attempt to ensure harmony and alignment with other ongoing or planned development and rehabilitation projects. Further, through the Zim-Fund, donors have developed common arrangements for planning, monitoring, evaluation and reporting.

\subsection{Mutual Accountability}

Donors have been critical on the urgency of carrying out a Joint Mid-term Review (JMTR) as 'a way of signalling the urgency of results to the Bank' (Interview, A21, A2, A23 and A1). However, for reasons that the researcher could not ascertain, the JMTR focused only on 'design and relevance, efficiency, effectiveness, impact, and sustainability' (Cleary et al., 2013). This is despite 'the rejection of the first prepared JMTR based on non-compliance with terms of references' (Interview, A23). ${ }^{9}$ Intentionally or inadvertently, the JMTR left out a detailed analysis of the Zim-Fund's compliance with bank rules and procedures, risk assessment and mitigation measures, the Zim-Fund contribution to donor coordination, compliance with the $\mathrm{M} \& \mathrm{E}$ of the Fund and project, and reviewing the Framework

\footnotetext{
${ }^{9}$ Joint Mid-term Review dated 30 April 2013.
} 
Agreement and the Operations Manual. It can be argued that not adhering to the JMTR terms of references can be interpreted as showing lack of accountability. If these terms of references were adhered to, the JMTR could have explained information as to who is accountable to what and how (Muchadenyika, 2013). Nonetheless, the main findings of the JMTR are (Cleary et al., 2013) as follows:

1. Design and relevance: The Zim-Fund is relevant thus addressing immediate emergency needs in an apolitical structure as demonstrated by the close proximity of priorities to the MTP. The design was a compromise between accommodating donors' political considerations (restrictive measures) and responding urgently to the cholera epidemic.

2. Efficiency: The layers of management within the Zim-Fund and the bank's procedures meant procurement took longer resulting in delays, which constrained efficiency.

3. Effectiveness: Since inception, no tangible results have been noted on the ground in the form of implementation. The process has been more complicated than anticipated casting doubts in the urgency nature of the fund.

4. Impact: At the time of the midterm review, no impact was discernible because contractors, generally, had not taken possession of sites. The impact is expected to be visible within the timeframe remaining to the Zim-Fund.

5. Sustainability: The Zim-Fund has a sustainable design that prioritises working with local authorities especially for hardware components. A major sustainability indicator for the Zim-Fund is its capacity to attract more donors although this has not happened.

The Zim-Fund Framework Agreement has clear timelines for the Zim-Fund reporting. There is evidence that most reports are prepared and delivered on time. However, 'operational challenges such as procurement portray a major stumbling block to reporting deadlines' (Interview, A18). The reporting compliance schedule especially for Implementing Entities is affected by procurement delays, a condition that complicates contract management and project implementation. The informal POC meeting of 19 July 2012 noted that despite the comprehensiveness of monthly and quarterly reports, there was need to find a format which is more useful for quick analysis by donors' (Informal POC meeting minutes, 19 July 2012).

The Zim-Fund monitoring processes are detached from government processes. Donors are even 'not aware of government monitoring processes' (Interview, A21). Nonetheless, the Government of Zimbabwe's monitoring processes are outlined in the Government Work Programme and MTP. The M\&E system for the Government Work Programme revolves on three sources of information, which are monthly ministerial reports on progress according to target work plans, budget expenditure reporting, provided to or by the Ministry of Finance and results-based management reporting (OPM (Office of the Prime Minister), 2010). In addition, the MTP gives priority to Results-based Management with long-term strategic goals, clear key outcomes and indicators, and a feedback and reporting system (GoZ (Government of Zimbabwe), 2011). There has been no attempt by the Zim-Fund to synchronise its monitoring processes with the mentioned government processes. 
At ministerial level, the Ministry of Finance does not directly account for the Zim-Fund projects to parliament as there has not been any specific report about the Zim-Fund tabled to the Parliament of Zimbabwe. This was confirmed by all the nine government officials interviewed. However, the Ministry of Finance reported to parliament about the Zim-Fund progress through Budget Statements for years 2012 (Sections 227, 228 and 229) (MoF (Ministry of Finance), 2011b) and 2013 (Section 467 and 468) (MoF (Ministry of Finance), 2012b), and Mid-year Fiscal Reviews for years 2011 (Sections 155-159) (MoF (Ministry of Finance), 2011a), 2012 (Sections 533-536) (MoF (Ministry of Finance), 2012a) and 2013 (Sections 383-391) (MoF (Ministry of Finance), 2012b). Moreover, 'reports from the POC are sent to Cabinet' (Interview, A14). Based on these, there is sufficient evidence to suggest that the Ministry of Finance is accountable to the legislature about Zim-Fund.

Mutual accounting for results is affected by four constraints. First, the project steering committee does not have the power to influence project management as stakeholders expected. This is despite its composition of technocrats who are mainly senior government and local authority officials. Second, accountability within the bank requires more scrutiny and analysis. For instance, to what extent does the AfDB Head of Region takes accountability of the Zim-Fund projects? The researcher could not find sufficient information to respond to this question. However, anecdotal evidence points to the inclination that accountability to the Zim-Fund by the AfDB Head of the Region seem to be weak as compared with other bank programmes running in Zimbabwe. Third, the ZimFund monitoring processes are detached from government processes. Fourth, the JMTR terms of references were not followed in entirety leaving out important information on accountability.

\subsection{Management for Results}

At the time of field research, the Zim-Fund was using a weak performance assessment framework basing on a progress tracking matrix and monthly reports, which do not show much about performance and indicators. Such a development is 'unexpected considering the AfDB's history in project management' (Interview, A21). Donor representatives argued that they are not happy with the current performance assessment framework as an M\&E system focused on projects implementation progress is not yet developed. The informal POC meeting held on the 19 July 2012 underscored 'the demand from donors, government ministers and beneficiaries to see tangible results on the ground' (POC meeting minutes, 19 July 2012). During a POC meeting held on the 29 December 2012, the Minister of Finance emphasised the 'Government of Zimbabwe's disappointment on the delay in the project implementation of the first phase projects' (POC meeting minutes, 29 December 2012). Further, the minister noted with concern 'the unacceptable low levels of disbursement and urged the AfDB to take stock of lessons learnt and introduce out-of-box solutions that would enable faster project implementation such as new formats and procedures for bidding processes' (Ibid). At the same meeting, 'donors underscored a M\&E framework and efficient reporting on results as a chief determinant to further financial 
commitments' (Ibid). This can be interpreted as commitment to results by both the Government of Zimbabwe and donors.

The POC reviews the Zim-Fund progress and provides a policy dialogue forum for the government, AfDB and the Zim-Fund donors. The POC gives policy guidance to the MMU. In 2012, 'dialogue within the POC was donor and not government-driven though a better donor-government balance has been restored' (Interview, A21). According to the Operations Manual, the POC meets on a quarterly basis or as often as required. In practice, POC meetings are infrequent and this has impacts on the management of the Zim-Fund projects. POC sessions were held on 19 October 2010, 21 January 2011 and 1 April 2011; 11 April 2012 and 29 November 2012. Informal POC meetings although usually without government representation, are a forum where detailed discussions take place. The informal POC meetings held on 19 July 2012 and 26 March 2013 had detailed background documents, which provided the basis for discussions.

Managing trust funds of a magnitude like 'the Zim-Fund provides new experience and a learning process to the AfDB' (Interview, A15). Therefore, 'the Zim-Fund is a pilot fund for the AfDB explaining why donors are patient and understanding to the delays faced in the projects' (Interview, A1). It seems that 'the AfDB does not have sufficient managerial capacity to run a complex fund like the Zim-Fund' (Interview, A2). Despite this, donors themselves do not have experts on MDTFs making engagement with the Zim-Fund a learning process as well. The challenges faced by the bank as the fund manager were captured as if the AfDB was a private company, donors would have sacked the implementing agency due to underperforming' (Interview, A2). One can argue that donors took a calculated risk as improving the structure of the MMU and the fund is incremental (an ongoing process based on lessons learned).

As of 12 June 2012; Germany, Norway, Sweden and Switzerland had not fully paid up their commitments. On a POC meeting held on the 29 November 2012, representatives of Germany and Norway informed the meeting that arrangements had been made to pay their pledges by the end of 2012. However, by July 2013, all donor representatives interviewed pointed that all donors have honoured their pledges. Thus, the Zim-Fund's challenge was presented as getting new commitments and new donors. In 2011, donors could not disburse additional funds because the Zim-Fund was yet to commence the implementation phase and the message was, 'deliver first before we [donors] make new commitments' (Interview, A21). For new financial commitments, 'Denmark has an additional US\$20 million budgeted for 2014 depending on the outcome of the midterm review and clearly demonstrated ability to accumulate and build fund operations on lessons learned so far' (POC meeting minutes, 29 November 2012). Tied commitments indicate lack of confidence with progress within the Zim-Fund. Slow progress made 'some donors to be sceptical about investing additional funding to the trust fund' (Interview, A22).

The Zim-Fund show unexpected results. The performance assessment framework is weak, and there is no M\&E framework. However, all donors and the Government of Zimbabwe 
are keen on developing a shared M\&E framework focused on implementation results. Three and half years after inception, the JMTR found no tangible results on the ground in the form of implementation. Lack of discernible implementation progress has raised concern by stakeholders mainly government, donors and local authorities.

\section{CONCLUSION}

Multi-donor trust funds are a prevalent aid mechanism in fragile states as it is widely believed that MDTFs are aid instruments that enhance aid effectiveness in fragile states (World Bank, 2011; Barakat et al., 2011). However, this article challenges this assertion by focusing on the Zim-Fund. In particular, the article has argued that the aid effectiveness of MDTFs is context specific and is largely influenced by politics and the institutional structure of the trust fund. The inception of the Zim-Fund coincided with a weak state, which has been dormant in mainstream international aid management with donors opting working through non-state actors. This background affected the subsequent adherence of the Zim-Fund to the Paris Declaration on Aid Effectiveness.

In summary, the article makes four key conclusions, which can be applied to MDTFs elsewhere. First, political relations between recipient and donor countries are vital in the functioning of MDTFs. Because of restrictive measures imposed on Zimbabwe by the USA and the European Union, and the political stand-off facing the country; the international community refrained from engaging directly with the Government of Zimbabwe. Despite this, the inception of the Zimbabwe Multi-donor Trust Fund is a cautious re-engagement strategy although showing commitment of the donor community to assist the early recovery of Zimbabwe's key development sectors (water, sanitation and energy).

Second, the design of MDTFs affects the delivery and functioning of the trust fund. A key element of designing a MDTF seems to be based on an incremental basis. This is mainly because, in fragile states, the socio-economic and political environment is often complex and in a state of flux. In addition, most donors and trust fund managers often lack the experience needed to manage MDTFs in fragile settings. Hence, trust funds often present a learning process in international re-engagement and aid management. At the same time, where there is no formal engagement arrangements between the recipient and donor governments; the use of neutral, acceptable and credible bodies as fund administrators is fundamental. This is despite that such 'neutral' arrangements often undermine recipient country systems.

Third, while the legitimacy of national governments in fragile states is often contested, targeting legitimate and credible institutions can offer tangible and life changing results. Target institutions and beneficiaries should be governments, in principle, but in practice, other state institutions that still have legitimacy, for example, local authorities. Fourth, MDTFs focusing on the recovery of key sectors such as water, sanitation and energy have direct impacts to economic recovery and people's lives. As such, the Zim-Fund is proving to be a key infrastructure investment fund addressing urgent and long-term service delivery 
issues. One would argue that MDTFs focusing on infrastructure rehabilitation and development have multiple ripple effects in the reconstruction of fragile states.

\section{ACKNOWLEDGEMENTS}

This research was largely conducted in the course of my Master thesis, presented to the Institute of Development Policy and Development Research, Ruhr University Bochum in 2013. I am indebted to Johannes Norpoth for countless comments, which aided this work. I wish to thank staff at AfDB, DFID, KfW, AUS AID, SIDA, SDC, Denmark and Ministry of Finance (Government of Zimbabwe) for their assistance during the field research. Errors of fact and interpretation remain my own. 


\section{REFERENCES}

Acemoglu D, Robinson AJ. 2013. Why Nations Fail: The Origins of Power, Prosperity and Poverty. Profile Books: London.

Addison T, Mavrotas G, McGillivray M. 2005. Development assistance and development finance: evidence and global policy agendas. Journal of International Development 17(2015): 819-836. DOI:10.1002/jid.1243

African Development Bank (AfDB). 2010a. Proposal to Strengthen Bank Presence in Zimbabwe.

African Development Bank Group: Regional Department South (ORSA): Pretoria.

African Development Bank (AfDB). 2010b. Framework of the Zimbabwe Multi-donor Trust Fund. Regional Department South Region A (ORSA): Pretoria.

African Development Bank (AfDB). 2010c. Zimbabwe Multi-donor Trust Fund Operations Manual. African Development Bank: Harare.

African Development Bank (AfDB). 2012. Zimbabwe Capacity Building for Public and Economic Management. Probable Date of Board Presentation: 5 December 2012.

Barakat S, Rzeszut K, Martin N. 2011. What is the Track Record of Multi-donor Trust Funds in Improving Aid Effectiveness? An Assessment of the Available Evidence. EPPI-Centre, Social Science Research Unit, Institute of Education, University of London: London.

Chapman N, Vaillant C. 2010. Synthesis of Country Programme Evaluations Conducted in Fragile States. Department for International Development: London.

Cleary S, Makurira H, James V. 2013. Mid-term Review: Zimbabwe Multi-donor Trust Fund (Zim- Fund) Zimbabwe, 11 March-30 April 2013 Final Report. 03 June 2013. African Development Bank: Harare.

Coppin E. 2012. Measuring Good Pooled Funds in Fragile States. Overseas Development Institute: London.

Dawson M, Kelsall T. 2012. Anti-developmental patrimonialism in Zimbabwe. Journal of Contemporary African Studies 30(1): 49-66. DOI:10.1080/02589001.2012.643010

Dore D. 2009. The Recovery and Transformation of Zimbabwe's Communal Areas. Working Paper 4. UNDP-Zimbabwe: Harare.

Feeny S, McGillivray M. 2009. Aid allocation to fragile states: absorptive capacity constraints. Journal of International Development 21(2009): 618-632. DOI:10.1002/jid.1502

GoZ (Government of Zimbabwe). 2011. Zimbabwe Medium Plan 2011-2015. Republic of Zimbabwe: Harare.

ICG (International Crisis Group). 2004. Blood and Soil. International Crisis Group: Brussels. ICG (International Crisis Group). 2009. Zimbabwe: Engaging the Inclusive Government. Africa Briefing No. 59. International Crisis Group: Brussels.

IEG (Independent Evaluation Group). 2011. Trust Fund Support for Development: An Evaluation of the World Bank's Trust Fund Portfolio. The World Bank Group: Washington DC.

Killen B, Rogerson A. 2010. Global Governance for International Development: Who Is in Charge? Development Brief Issue 2/2010. OECD: Paris. 
Kim EM, Lee EJ. 2013. Busan and beyond: South Korea and the transition from aid effectiveness to development effectiveness. Journal of International Development 25(2013): 787-801. DOI:10.1002/jid.2938

Koster KD, Holvoet N. 2012. Bilateral Donors' efforts to assess and manage UN Agencies' effectiveness: seeking a balance between Paris principles and domestic accountability. Development Policy Review 30(4): 399-424.

Manuel M, McKechnie A, King M, Coppin E, Denney L. 2012. Innovative aid Instruments and Flexible Financing: Providing Better Support to Fragile States. Overseas Development Institute: London.

Mawdsley E, Savage L, Kim S-M. 2013. A 'post-aid World'? Paradigm shift in foreign aid and development cooperation at the 2011 Busan High-level Forum. The Geographical Journal 180(1): 27-38. DOI:10.1111/j.1475-4959.2012.00490.x

Mbeki M. 2009. Architects of Poverty: Why African Capitalism Needs Changing. Picador Africa: Johannesburg.

MEPIP (Ministry of Economic Planning and Investment Promotion). 2012. First Annual Medium Term Plan (MTP) 2011-2015 Implementation Progress Report. Harare: Ministry of Economic Planning and Investment Promotion.

MoF (Ministry of Finance). 2011a. Mid-Year Fiscal Review Statement: Riding the Storm: Economics in the Time of Challenges. Presented to the Parliament of Zimbabwe on 26 July 2011 By The Hon. T. Biti (M.P), Minister of Finance. Ministry of Finance: Harare.

MoF (Ministry of Finance). 2011b. The 2012 National Budget Statement: Sustaining Efficient Inclusive Growth with Jobs. Presented to the Parliament of Zimbabwe on Thursday, November 24, 2011 by The Hon. T. Biti (MP), Minister of Finance. Ministry of Finance: Harare.

MoF (Ministry of Finance). 2012a. The 2012 Mid-Year Fiscal Policy Review Statement: "From Crisis to Austerity: Getting Back to Basics". Presented to the Parliament of Zimbabwe on Wednesday, July 18, 2012 By The Hon. T. Biti (M.P), Minister of Finance. Ministry of Finance: Harare.

MoF (Ministry of Finance). 2012b. The 2013 National Budget Statement: "Beyond the Enclave: Unleashing Zimbabwe's Economic Growth Potential". Presented to the Parliament of Zimbabwe on November 15, 2012 By The Hon. T. Biti (M.P), Minister of Finance. Ministry of Finance: Harare

MoF (Ministry of Finance). 2013. The 2013 Mid-Year Fiscal Policy Review Statement. Ministry of Finance: Harare.

Muchadenyika D. 2013. Rethinking the Role of the State in Development. Assessing the Performance of Multi-donor Trust Funds: The Case of the Zimbabwe Multi-donor Trust Fund (Zim-Fund). Unpublished MA Thesis. Institute of Development Research and Development Policy, Ruhr-Universität Bochum: Bochum.

Odén B, Wohlgemuth L. 2011. Where is the Paris Agenda Heading? Changing Relations in Tanzania, Zambia and Mozambique. ECDPM Briefing Note 21. European Centre for Development Policy Management: Maastricht.

OECD. 2012. International Support to Post-Conflict Transition: Rethinking Policy, Changing Practice, DAC Guidelines and Reference Series. OECD: Paris. 
OECD. 2013. Fragile States: Resource Flows and Trends, Conflict and Fragility. OECD: Paris. OECD/DAC. 2007. Principles for Good International Engagement in Fragile States and Situations. OECD: Paris.

OPM (Office of the Prime Minister). 2010. Government of Zimbabwe: Government Work Plan (GWP) 2010. Office of the Prime Minister: Harare.

Open Society Initiative for Southern Africa (OSISA). 2007. Constitutional Review and Reform: And the adherence to Democratic Principles in Constitutions in Southern African Countries. Open Society Initiative for Southern Africa: Johannesburg.

Paris Declaration. 2008. Paris Declaration on Aid Effectiveness and the Accra Agenda for Action. OECD: Paris.

Rogerson A. 2005. Aid Harmonisation and Alignment: Bridging the Gaps between Reality and the Paris Reform Agenda. Development Policy Review 23(5): 531-552.

Schiavo-Campo S. 2003. Financing and Aid Management Arrangements in Post-conflict Situations. CPR Working Paper No. 6. World Bank Social Development Department: Washington DC.

UNDP. 2008. Comprehensive Economic Recovery: A Discussion Document. UNDPZimbabwe: Harare.

UNDP. 2009. International Aid and its Management: Some Insights for Zimbabwe in the Context of Re-engagement. Working Paper 2. UNDP-Zimbabwe: Harare.

UNDP. 2010. State Effectiveness, Economic Recovery and Poverty Reduction: Some Evidence from the Global Experience for Zimbabwe. Working Paper 12. UNDP-Zimbabwe: Harare.

Unsworth S. 2009. What's Politics Got to Do With it?: Why Donors Find it so Hard to Come to Terms With Politics, and why This Matters. Journal of International Development 21(2009): 883-894.

World Bank. 2011. World Development Report 2011: Conflict, Security and Development. The World Bank: Washington DC.

Zimbabwe Democracy and Economic Recovery Act. 2001. (S24) Enacted by the Senate and House of Representatives of the United States of America in Congress assembled, One Hundred Seventh Congress of the United States of America at the First Session Begun and held at the City of Washington on Wednesday, 3 January 2001.

Zimbabwe Institute. 2007. Progressive Zimbabwe: Sustainable Growth and Transformation. Zimbabwe Institute: Cape Town. 